\title{
Data Identification of Cirebon Batik West Java Source of Strength Geographical Indication
}

\author{
Komarudin Kudiya ${ }^{1}$, Miranda Risang $\mathrm{Ayu}^{2}$ \\ 1 Universitas Muhammadiyah Bandung \\ 2 Universitas Padjadjaran \\ Email: kkudiya@ymail.com
}

\begin{abstract}
In the history of batik in Indonesia, We used to know that batik is identified with Javanese culture. In addition, the use of batik cloth is limited to the royal court with a variety of very strict rules. But in its development, batik is no longer owned by Javanese, batik has now become one of the "national clothes" of Indonesia that is used by Indonesians throughout the archipelago on various occasions. In West Java batik has grown and developed in 27 regencies / cities spread from the eastern part of the Cirebon district to the western of West Java, Depok. There are potential characteristics and excellences from each region in West Java that people could not find in other regions. The uniqueness and characteristics of batik in certain area are part of the protection system of geographical indications that identify an area of the country, as the origin region of the product, where the reputation, quality and characteristics of related products are largely determined by geographical factors in the region. The need for a complete and accurate identification in the protection of Geographical Indications is very important considering batik products in West Java have enormous potential that can be protected as part of Geographical Indications (IG) which can be used as marketing tools in the world of commerce, both at the national and international level.
\end{abstract}

Keywords: Cirebon Batik, Geographical Indication, Identification

Abstrak

Dalam sejarah batik di Indonesia dulu kita tahu bahwa batik diidentikkan dengan budaya Jawa. Selain itu, penggunaan kain batik dibatasi pada lingkungan keraton dengan berbagai aturan yang sangat ketat. Namun dalam perkembangannya batik tidak lagi dimiliki oleh orang jawa, batik kini telah menjadi salah satu "pakaian nasional" indonesia yang digunakan oleh masyarakat indonesia di seluruh nusantara dalam berbagai kesempatan. Di Jawa Barat batik telah tumbuh dan berkembang di 27 kabupaten / kota yang tersebar mulai dari Kabupaten Cirebon bagian timur sampai dengan Jawa Barat bagian barat, Depok. Terdapat potensi ciri dan keunggulan masing-masing daerah di Jawa Barat yang tidak dapat ditemukan di daerah lain. Keunikan dan ciri khas batik pada suatu daerah merupakan bagian dari sistem perlindungan indikasi geografis yang mengidentifikasikan suatu daerah suatu negara, sebagai daerah asal suatu produk, dimana reputasi, kualitas dan karakteristik produk terkait sangat ditentukan oleh faktor geografis. di wilayah tersebut. Kebutuhan akan identifikasi yang lengkap dan akurat dalam perlindungan Indikasi Geografis sangat penting dilakukan mengingat produk batik di Jawa Barat memiliki potensi yang sangat besar yang dapat dilindungi sebagai bagian dari Indikasi Geografis (IG) yang dapat digunakan sebagai alat pemasaran dalam dunia perdagangan, baik di tingkat nasional maupun internasional.

Kata Kunci: Batik Cirebon, Indikasi Geografis, Identifikasi

Copyright@2020KosmikHukum.All rights reserved.

\section{Introduction \\ 1. Background \\ a. Overview of Batik in West Java}

In Sundanese old manuscript -“Siksa Kanda ng Karesian" beginning of the 16th century with regard to batik artifact, contains the facts referred to "called various types of painting (Hand-drawn): pupunjengan, hihinggulan, kekembangan, alas-alasan, urang-urangan, memetahan, sisirangan, taruk hata, kembang tarate, also called boeh (Various fabrics): kembang mu(n)cang, gagang senggang, anyam cayut, poleng re(ng)ganis, cecempaan, mangin haris, surat awi, parigi 
nyengsoh, hujan riris; which shows that at the time the manuscript was written, the Sundanese people were familiar with various shades of cloth and batik. Even though there are no relics from the Sunda Kingdom, several pieces of cloth 200-300 years old have been found". ${ }^{1}$

In the history of the development of human civilization, we would examined various stages. One of the important step is to produce clothing material. In the past, clothing materials were made of bark which beaten to be flat. As the time goes by, people got to know the spinning and weaving techniques, which produced yarn woven fabrics. The next development is to decorate it. Colored, decorated with certain patterns (motifs, decoration), and so on. ${ }^{2}$ Based on the dictionary, ${ }^{3}$ batik is explained as a special motif cloth that is made by writing or applying wax on it, then processed in a certain way; or commonly known as batik cloth.

Etymologically, the word batik comes from the Javanese language, "amba" which means width, large, fabric; and "titik" which means a dot or matik (making a dot) which then develops into the term "batik", which means connecting the dots into certain images on a fabric. Batik also known as everything which connected in order to make certain points on the cloth. In Javanese, "batik" is written with "bathik", referring to the Javanese letter "tha" which shows that batik is a series of dots that form a particular picture. Based on the etymology, actually "batik" cannot be interpreted as one or two words, or one-word equivalent without further explanation. ${ }^{4}$

According to Hanggopuro, The writers in past using the term batik which is actually not written with the word "batik" but should "bathik". This refers to the Javanese letters "tha" not "ta" and the use of bathik as a series of dots is incorrect. Based on the etymology, batik is actually identical with a technique (process) from the depiction of motifs to pelorodan (process of removing the wax). One of the characteristics of batik is a way of depicting the motif on the fabric through the process of deepening, people scratch the hot wax liquid using a tool called canting. ${ }^{5}$ According to Hamzuri, batik is a way to embellish fabrics by covering certain parts by using resistance. The resisntance that is often used is wax. Fabrics that have been drawn using wax then colored by dyeing it into the color. After that remove the wax by boil it using boiling water and sodium carbonate. ${ }^{6}$

The phrase batik according to the Petarekan Cirebon (followers of the tarekat in Cirebon), is an abbreviation of ba titike ning esor, bagiya sing andhap asor, it means, the letter 'ba' (the second letter in hijaiyah, Arabic) has a dot at the bottom, means blessed people be humble. The letter 'ba' according to the Petarekan (followers of the tarekat) is very important because it is the initial letter of the phrase 'Bismilaahirrohmaanirrohiim' as stated at the base of the Cirebon flag batik (Singa Barwang Duajilullah), which means "In the name of Allah, Most Gracious, again AllMerciful". Batik is also a tool for storing "a certain spirit or ideals, which are conveyed as treatises or messages for the next generation, so that the shared ideals will remain alive and not fade. The same thing as a message storage media is also contained in other traditional Cirebon art products, including: stone (gravestone), wood (carving), glass painting, and ceramics or earthenware, in addition to those printed on daluang or lontar paper manuscripts (rontal). ${ }^{7}$

Furthermore, the Petarekan said that the term of 'batik' would be 'kitab (holy book)' when spelled backward. Apart from the term of tweaking the Javanese gatuk, which can be interpreted as a word that is forced to have a connection or bond. Kitab as it is known and understood is a collection of texts that have been compiled into a book that contains guidelines, lessons, procedures or rules that teach about human life. As is the case in batik that sometimes

\footnotetext{
Rosidi, Ajip; Ekadjati, Edi S.; Alwasilah, A. Chaedar, 2006, Konferensi Internasional Budaya Sunda (KIBS), Jilid 1, Bandung: Yayasan Kebudayaan Rancage dan PT Dunia Pustaka Jaya

Tirta, Iwan. Batik Sebagai lakon, Jakarta: Gaya Favorit Press, 2009

KBBI, 2016. Kamus Besar Bahasa Indonesia (KBBI).

Indonesia Indah Batik 8. Jakarta: Yayasan HarapanKita/BP3 Taman Mini Indonesia Indah

Honggopuro, Kalinggo. 2002. Batik Sebagai Busana Dalam Tatanan dan Tuntunan. Yayasan Peduli Keraton.

Hamzuri. 1985. Batik Klasik (Classical Batik). Jakarta: Djambatan.

Irianto, Bambang drh. Makna Simbolik Batik Keraton Cirebon: Deepublish, 2015
} 
Kosmik Hukum Vol. 20 No. 2 (2020): 103-113

E-ISSN: 2655-9242 | P-ISSN: 1411-9781

DOI: 10.30595/kosmikhukum.v20i2.6954

found a noble philosophy about the lessons of human life, or expressions of hope and prayer, as befits a kitab. ${ }^{8}$

Besides in Central Java, batik developed in West Java Province which also has a unique style and characteristics. Among the cities in West Java that produce batik are Cirebon, Indramayu, Tasikmalaya, Ciamis and Garut. One if the city still maintains the tradition of batik, Garut, and the batik called original Garut Batik. Garut batik motifs include coastal naturalistic types of batik, while the distinctive color is the color of gumading. ${ }^{9}$ However, there are similarities or influences in the decoration of Yogyakarta and Solo regions, as well as areas in West Java itself such as Cirebon and Indramayu with Garutan's taste and style adjustments. Reviewed and the motifs, colors and color settings as well as the style, the batik in the West Java region which is now scattered in 27 City Regencies, will provide how rich and beautiful diverse decoration and batik patterns that are in West Java. The techniques and experience possessed by the people of West Java gave birth to several techniques in making batik that are not owned by any region, not only in the batik-producing areas that are in the West Java region even in almost all corners of the archipelago.

There are several superiorities of Cirebon West Java batik crafters techniques that are not possessed by others. The technique of creating small, thin lines without breaking with light / dark colored cloth background, while dark / dark colored outlines, this technique is called merawit. This technique is only owned by batik artisans in the Trusmi Plered Cirebon area, precisely in Gamel, Wotgali and Kaliwulu villages, Plered District, Cirebon Regency, West Java. The hallmark of Cirebon batik is that it is able to make thin and firm line (wit). ${ }^{10}$ The superiority of this technique is the process of identification and preparation of documents that will soon be registered as a Geographical Indication (IG) of Trusmi Cirebon batik in the future.

The results of the depiction of batik are called by the name of decoration or known as motifs. Generally the appearance of the motif is strongly influenced and is closely related to factors such as the geographical location of batik makers, the nature and order of life, beliefs and customs, natural conditions, and the presence of contacts or relationships between batik areas. ${ }^{11}$ Therefore, to know the art of batik can be viewed from various aspects such as the manufacturing process, the quality of batik, and the motifs and colors. As a result of the geographical location of the Indonesian archipelago which is in the trade route, especially in coastal areas, it has at least influenced the local culture (art).

\section{b. Geographical Indication Potential in West Java}

Biodiversity and non-biological wealth in West Java is very abundant. It requires careful attention, care and a very high sense of ownership for the people of West Java and the West Java government in particular to immediately identify the potential of the wealth to be registered in the Geographical Indications (IG) at the Ministry of Law and Human Rights. Lack of attention and ownership of all IG potentials will result in huge losses for the people of West Java in particular. Because the greatest benefit for objects that have received an IG certificate will have an impact on increasing economic values. Economic Benefits of IG Protection include: (1) IG is an immaterial asset that gets legal protection, which contains the message of the good reputation of certain products, is a sign of good and distinctive quality. (2) IG can be a superior product with high economic value. (3) The collective approach of an IG product can provide benefits to small farmers, because generally they will not be able to finance marketing activities individually. (4) If the reputation is already owned, then small farmers will benefit from IG protection related to obtaining a niche market.

Until the end of 2019, West Java had 8 registered IGs including the following: 1. Tembakau Hitam Sumedang which registered by the MPemb Sumedang Tobacco Association,

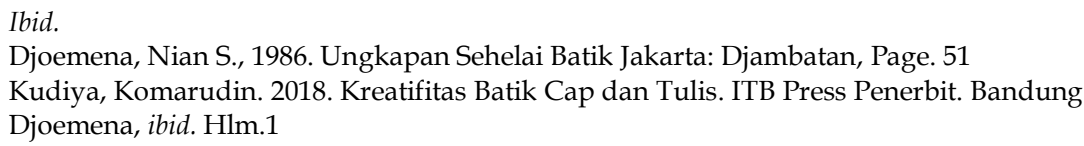


2. Tembakau Mole Sumedang which registered by MPIG Sumedang Tobacco, 3. Ubi Cilembu Sumedang which registered by the Cilembu Sweet Potato Agribusiness Association (ASAGUCI), 4. Beras Pandanwangi Cianjur which registered by the Pandanwangi Cianjur Rice Conservation Society (MP3C), 5. The Java Preanger which registered by MPIG Java Preanger Tea, 6. Kopi Arabika Java Preanger which registered by MPIG Arabica Java Preanger Coffee. 7. Sawo Sukatali Sumedang which registered by Sawo Farmers Association (ANISA). 8. Kopi Robusta Java Bogor.

The West Java Government has an interest to immediately initiate Arabica coffee for the districts of Bandung, West Bandung, Garut, Sumedang and Subang. During this time West Java has had two variants, IG Kopi Arabika Java Preanger (KAJP); 1). Bandoeng Highlant (coffee grown in the Gunung region; Cikuray, Papandayan, Malabar, Tilu, Patuha, Halu, Beser), 2). Soenda Mountain (coffee grown in the Gunung region; Burangrang, Tangkuban Perahu and Manglayang). Other places in West Java that have the potential to be IG delivered include Robusta coffee for the districts of Bogor, Ciamis, Cianjur, Kuningan, Pangandaran, Sumedang and Tasikmalaya. As for cocoa products, it will be initiated in the areas of Ciamis, Pangandaran and Sukabumi districts. For cloves will be initiated in the districts of Bandung, Bogor, Ciamis, Cianjur, Garut, Kuningan, Majalengka, Purwakarta, Subang, Sukabumi, Sumedang and Tasikmalaya.

Data on the results of the IG potential inventory is very important for relevant stakeholders, as one of the efforts to preserve intellectual property, because the preservation of intellectual property through an IG certificate is a sign that indicates the area of origin of goods and / or products due to geographical environmental factors including natural factors, human factors or a combination of the two. At the end able to provide reputation and quality, and certain characteristics of the goods and / or products produced. Commodities of plantation products, especially in West Java such as robusta coffee, cloves, cocoa, fragrant roots, sugar are plantation products that if they have a characteristic or sign can be registered by the IG. West Java Province will soon issue IG Kopi Robusta Java Bogor, currently in the data verification stage at Ministry of Law and Human Rights

There are so many IG potential from West Java, such as Arabica Coffee, Robusta Coffee, Garut Fragrant Roots, Palm Sugar / coconut sugar (shell sugar, ant sugar), Cinnamon, Cocoa and others. Thus the initiation of the IG region is very appropriate to be carried out, if necessary continuously every year to explore all the potential of plantation products in West Java (Source: West Java Plantation Office).

In the protection registration of IG, objects that can be registered include natural resources, handicraft items and industrial products. Therefore, in initiating an IG, it is necessary to pay attention from the outset about the name of the item and / or product to be protected by Geographical Indications. The product must be able to describe its characteristics and quality, as well as its relationship to the region, its geographical environment (natural and human factors), regional boundaries, history and traditions related to geographical indications, production, processing and manufacturing processes, methods used to test quality, the label to be used on the item in question.

Based on the Regulation of Law and Human Rights No. 12 of 2019 concerning Geographical Indications regarding registration procedures contained in Chapter II Requirements and Procedures for Geographical Indications Registration consists of several stages, namely the stage of filing an application, administrative examination (completeness of documents), substantive examination, site visit, opposition to registration, registration, supervision on the use of Geographical Indications and the stage of appeal if a refusal occurs. The Director General of Intellectual Property (Ditjen KI) of the Ministry of Law and Human Rights, Freddy Harris, explained that there are at least 3 reasons why a product with geographical indication (IG) must be registered. First, relating to the protection of geographical names. This means that when a product is registered as an IG, then no one else can use the 
Kosmik Hukum Vol. 20 No. 2 (2020): 103-113

E-ISSN: 2655-9242 | P-ISSN: 1411-9781

DOI: $10.30595 /$ kosmikhukum.v20i2.6954

geographical name on similar products. Second, guarantee the authenticity of the origin of a product. Third, product quality assurance.

\section{c. Batik sebagai produk PT dan EBT}

Batik, which is a noble heritage of the ancestors of the Indonesian people, is undoubtedly a part of Traditional Knowledge and Traditional Cultural Expressions (Expressions of Folklore) which have been completed in terms of Indonesian culture. Batik as one of the forms of traditional intellectual property EBT has enormous cultural value as a form of cultural heritage that continues to develop even in modern societies around the world. While on the other hand, PTEBT also plays an important role as part of social identity and cultural expression of a local community. The expression of Indonesia's traditional culture has promising economic potential, especially related to the tourism industry and the creative economy industry. In the creative economy industry, especially EBT-based handicraft products such as batik, wood carving, copper carving, silver are products that have a significant contribution to the country's foreign exchange.

Protection against EBT which bases the existing legal principles on the principles of intellectual property law, which can be through the principles that exist in the provisions of copyright and industrial property law that currently exists apply at both international and national levels. When mentioning the legal system, many of us refer to Friedman who mentions the existence of three elements, namely material, substance, and culture. First, we will discuss the protection of EBT through the substance of intellectual property law, especially through the principles existing law in the provisions of copyright law and industrial property law. ${ }^{12}$

\section{d. The Condition of Cirebon Batik, West Java in Indonesian Batik Mosaic Scene}

Dennys Lombard (1990) says that the oldest designation about batik is found in a Sundanese text found in southern Cirebon and dated 1440 Saka / 1518 M. Based on interviews conducted with Sultan Sepuh PRA. H. Arief Natadiningrat SE, said that the making of batik craft has existed since the time of the prince Cakrabuwana, but there was no mention of the exact year because there was no evidence of writing or manuscripts, but he could show ancient batik collections from Sunan Gunung Jati that were thought to have existed since 15th century M. Cirebon Batik has a production group which is divided into a) Keraton Batik, b) Coastal Batik and c) Ciwaringin Batik.

Batik Keraton has sources of inspiration from (1) Kencana trains such as the Singa Barong Train, Jempana Train, and Paksinaga Liman Train; (2) carved ornaments found on doors, ornaments, wood carvings and stone carvings; (3) the building (landscaping) of the Dalem Agung Pakungwati Park, the Sunyaragi Cave Water Park, Astana Gunung Jati, and the objects contained therein; (4) Ceramics brought by migrants from China; and (5) Cirebon Wayang Golek and Cirebon Wayang Kulit.

While the coast batik inspiration mostly came from the migrants outside the Cirebon region, even outside the island of Java who deliberately look for batik products with the characteristics of their respective regions, but are done in the Cirebon region. More precisely Cirebon coastal batik has a bright style and variety of decoration and many colors (multi color) with a very diverse decoration. Coastal Batik Cirebon is more concerned with commercial / economic aspects as inter-island trade goods.

Ciwaringin batik, which is on the Cirebon map located in the western, the inspiration came from Lasem, Central Java. This is because the KH. Mohammad Amin (Ki Madamin) who teaches batik in the Ciwaringin area is a former santri studying religion in the Lasem area. Ki Madamin Muda studied religion, also studied batik. Cirebon batik in the Cirebon batik scene

12 These three principles based on Lawrence M. Friedman, 1984, American Law, An Introduction, , New York, W.W. Norton and Company, juga dalam Lawrence M.Friedman,1973, A History of American Law, NewYork, Simonand Schuster. 
has given birth to thousands of Cirebon batik ornaments, and has also enriched hundreds of batik ornaments in areas outside the city of Cirebon. This is because the artisans in the Cirebon area also produce a variety of patterns and decoration of batik outside the Cirebon region.

Based on the background of the research, the writer can formulate several problems as follows: First, How is the effort of the Cirebon Regency government - West Java Province to identify the existence of Cirebon batik as an Economic and Cultural force; Second, How to provide protection against Cirebon Batik which is a strategic source of Geographical Indications.

\section{Research Methods}

This research was conducted using the empirical juridical approach method or the statutory approach. That is the law is not only seen as rules, but also includes the operation of law in society. With a descriptive analytical, this research is intended to provide details, systematic and comprehensive picture of everything both legislation and legal theories. ${ }^{13}$ The types and sources of data in this study use primary data and secondary data. Primary Data is data obtained directly from field research.

Secondary data is data that obtained based on literature study intended to compare between theory and reality that occur in the field through this literature study, data collection is attempted by studying books, articles and the internet as well as other references related to this research, secondary data in this research include: primary, secondary and tertiary legal materials. Research is only conducted on those selected as respondents. Determination of respondents was done by purposive sampling. ${ }^{14}$ Based on these considerations, the samples of this study are as follows: Sultan Sepuh IX PRA H. Arief Natadiningrat SE, Culture Cirebon Cirebon drh. H. Bambang Irianto, Erwin Ibrahim Ir., Secretary of the Indonesian Batik Craftsmen and Entrepreneurs Association (APPBI), H. Abdul Qodir S.Ag Cirebon batik artisans, Cirebon traditional Katura batik artisans, using the descriptive analytical data analysis method.

\section{Theoretical Framework}

In this study, researchers conducted activities by taking the term identification. Identification is the process of recognition, placing objects or individuals in a class according to certain characteristics. ${ }^{15}$ According to Poerwadarminto the term "identification is the determination of the identity of a person or object". ${ }^{16}$ According to the psychoanalyst, identification is a process carried out by someone, unconsciously, in whole or in part, on the basis of an emotional bond with a particular character, so that he behaves or imagines himself as if he were the character. ${ }^{17}$ Based on the state of the experts above, it can be concluded that identification is a real condition or condition of the identity of a person or object at a certain time.

The definition of Geographical Indications is one type or regime of Intellectual Property Rights other than Patents, Copyrights, Confidential Information / Trade Secrets and several other types of intellectual property rights. Geographical indication is a trade name that is associated, used or attached to the packaging of a product and serves to indicate the origin of the product. The origin of the place implies that the quality of the product is greatly influenced

\footnotetext{
Ronny Hanitijo Soemitro, 1983, Metodologi Penelitian Hukum dan Jurimetri, Ghalia Indonesia, Jakarta, hlm.97.

Lexy J Moleong, 2006, Metodelogi Penelitian Kualitatif, PT.Remaja Rosdakarya, Bandung,hlm.112

15 Chaplin, J.P. 2008. Kamus Lengkap Psikologi. Diterjemahkan oleh Kartini Kartono. Jakarta: PT Raja Grafindo Persada.

16 Poerwadarminta. 2007. Kamus Umum Bahasa Indonesia. Jakarta: PN Balai Pustaka.

17 Calvin S. Hall (1959). Sigmund Freud. Suatu pengantar ke dalam ilmu jiwa Sigmund freud. Jakarta. PT. Pembangunan
} 
Kosmik Hukum Vol. 20 No. 2 (2020): 103-113

E-ISSN: 2655-9242 | P-ISSN: 1411-9781

DOI: 10.30595/kosmikhukum.v20i2.6954

by it, so that the product has a unique value in the minds of the public, especially consumers, who know that the place of origin does have a special advantage in producing a product. ${ }^{18}$

\section{Results and Discussion}

\section{Results of Data Identification of irrefutable sources for the strength of Indonesian Batik Culture}

Accuracy of Cirebon District population data based on the Central Bureau of Statistics of Cirebon District is the basis for the author to obtain data for which accuracy can be accounted for. Particularly, the author will look for data related to population in areas that produce batik crafts to support the potential of batik crafts in Cirebon District. Areas that produce Cirebon batik crafts are focused on Plered and Ciwaringin Sub-Districts, Cirebon District.

Based on the Central Bureau of Statistics of Cirebon District, the total population of Plered Sub-District of Cirebon District is in accordance with the population projections in 2018 of 55,303 inhabitants consisting of 28,059 male residents and 27,244 female residents. The number of population aged 15 years and over who worked in the field of agricultural business in 2018 was 1,732 men, while in services sector was 11,124 men. The registered job seekers in Plered Sub-District were mostly lived in Tegalsari Village with a total of 8,272 people, while the least number of job seekers were in the Trusmi Wetan Village with a total of 2,489 people.19 Based on population projections in 2018, the population of Ciwaringin Sub-District is 36,422 people consisting of 18,714 male residents and 17,708 female residents. ${ }^{20}$

\section{a. Data of Batik Craftsmen in Cirebon, West Java, Indonesia}

The data of batik craftsmen located in 2 (two) areas of Plered and Ciwaringin SubDistricts is based on data obtained from the West Java Batik Foundation/ Yayasan Batik Jawa Barat (YBJB) in 2018 of 1,625 people. The batik craftsmen are mostly located in the Plered SubDistrict of 1,405 people originating from Panembahan, Trusmi Wetan, Trusmi Kulon, Sarabau, Gamel, Wotgali, and Kaliwulu Villages. The center of the batik business is in Trusmi Kulon and Panembahan Villages. Meanwhile, the number of batik craftsmen in Ciwaringin Sub-District is 220, not as many as in the Plered Sub-District. Of the two sub-districts in Cirebon District, they occupy $54 \%$ of the total number of batik craftsmen in West Java. Meanwhile, when compared with the total number of batik craftsmen throughout Indonesia, which amounted to 131,565 people, then it occupies the amount of $1.23 \%$ of the total batik craftsmen from all over Indonesia. This makes West Java batik craftsmen ranks the third largest below Central and East Java Provinces based on the data obtained from the Indonesian Batik Craftsmen and Entrepreneurs Association/ Asosiasi Perajin dan Pengusaha Batik Indonesia (APPBI). ${ }^{21}$

\section{b. Data of Cirebon Batik Production in West Java, Indonesia}

Batik fabric produced by traditional batik craftsmen, particularly in Cirebon District can be classified into batik with handmade quality and stamped quality, or a combination of the two techniques. The type of production consists of long fabric (jarik), sarong shawl fabric, blouse material, shirt material, shawl, scarf, and batik tie. The composition of the types of production that are mostly produced as ranked from the highest are 1) blouse material, 2) shirt material, 3) long fabric, 4) shawl sarong, and 5) scarf or veil. The production number of types of

18 Risang Ayu, Miranda. 2006. Memperbincangkan Hak Kekakyaan Intelektual Indikasi Geografis, Bandung, PT. Alumni

19 Central Bureau of Statistics Cirebon District 2019. Plered Sub-District in Numbers Page. 16

20 Central Bureau of Statistics Cirebon District 2019. Ciwaringin Sub-District in Numbers Page. 15

21 Data of Craftsmen, Entrepreneurs, and Trade of Indonesian Batik in 2019 from the Indonesian Batik Craftsmen and Entrepreneurs Association (APPBI) 
printed batik can reach 3.5 million pieces/year and 22 thousand pieces/year for batik with good quality. ${ }^{22}$

Batik fabrics produced by most craftsmen in Cirebon District are not only used by the people of West Java. However, most batik craftsmen in Cirebon District produce orders for batik fabric with patterns and motifs from outside West Java Province. Some production of batik fabrics in Cirebon District is an order from Sumatra (Palembang, Jambi, Lampung, and Aceh).

\section{Batik as Potential Geographical Indications of West Java that need to be registered}

Almost the entire international world start to concern with the need for protection of Geographical Indications (GI), so that various international agreements regulate it. International legal protection of geographical indications can be found in the Paris Convention for the Protection of Industrial Property in 1983 and the Madrid Agreement in 1891. Both agreements state that "Indication of Source as an indication referring to a country or a place in that country, as being the country or place of origin of a product." 23 that:

Article 22 of the TRIPs Agreement also regulates Geographical Indications which state

Geographical indications are for the purposes of this agreement, indications which indentify a good as originating in the territory of a member, or a region or locality in that territory, where a given quality, reputation or other characteristics of the good is essentially attributable to its geographical origin.

The TRIPs Agreement provides the definition of a Geographical Indications as a sign that identifies an area of a member country, or region or district within that area as the origin of the goods, where the reputation, quality, and characteristics of the goods concerned are largely determined by geographical factors. Therefore, the origin of a particular item that is attached to the reputation, characteristics, and quality of the item associated with a certain area is protected legally.

In Indonesia, geographical indications have been regulated and adjusted to several international agreements, although substantially not absolutely the same. In the formal Constitution and laws of the Republic of Indonesia, geographical indications are regulated in Law number 15 of 2001 concerning Trademarks in Article 56 paragraph 1 which states: "Geographical indications are protected as a sign indicating the area of origin of goods, which due to geographical environmental factors. including natural and human factors, or a combination of the two factors so as to give particular characteristics and qualities to the goods produced."

On the process of government support for geographical indications in the Law of Trademarks, the Government issued Government Regulation (PP) No. 51 of 2007 which regulates technically about Geographical Indications. The latest one is the Regulation of the Minister of Law and Human Rights Republic of Indonesia No. 12 of 2019 concerning Geographical Indications. Regarding the potential of Geographical Indications in Indonesia, many can be utilized to compete internationally, but until the end of 2019, only 68 potential

22 Data of Craftsmen, Entrepreneurs, and Trade of Indonesian Batik in 2019 from the Indonesian Batik Craftsmen and Entrepreneurs Association (APPBI)

23 Achmad Zen Umar Purba, "International Regulation on Geopraphical Indications, Genetic Resources and Traditional Knowledge", Workshop on the Developing Countries Interest to Geographical Indications, Genetic and Traditional Knowledge, PIH FHUI and Dit.Gen of IPR's, Dept.of Law and Human Rights , RI, Jakarta, April 6, 2005, page. 37. 
Kosmik Hukum Vol. 20 No. 2 (2020): 103-113

E-ISSN: 2655-9242 | P-ISSN: 1411-9781

DOI: 10.30595/kosmikhukum.v20i2.6954

Geographical Indications have been successfully registered at the Ministry of Law and Human Rights from all over Indonesia. Of these, 8 are GIs from West Java.

Batik as a part of Traditional Knowledge and Traditional Cultural Expressions (PT-EBT) is protected by Law of Patents. In the Indonesian Property Rights/ Hak Kekayaan Indonesia (HKI) regime, batik is also included in the legally protected Intangible Cultural Heritage. The legal products of this HKI include protection of Geographical Indications.

The benefit of the potential advantages batik owned by West Java will be achieved maximally by the community of craftsmen if the West Java government swiftly and immediately protect its distinctive products with a Geographical Indication protection system. From this point on, protection of Geographical Indications nationally as well as internationally is strongly needed. Several advantages of international protection include: a). Geographical Indications can be used as a product marketing strategy in domestic and foreign trade, b) provide added value to the products and improve the welfare of the craftsmen, c). enhance the reputation of Geographical Indications products in international trade, d). equality of treatment as a result of international promotions, and e). protection of Geographical Indications as a way to avoid fraudulent competition.

\section{Correlation of Cultural and Economic Values of Batik - Cirebon District, West Java in Geographical Indications}

Before we discuss the relationship of the correlation between cultural and economic values, we should first recognize the meaning of cultural values. They consist of conceptions that live in the realm of mind of most people in things they consider exceptionally noble. The value system that exists in a community becomes the orientation and reference in acting according to Koentjaraningrat.

Up to nowadays, if we look carefully, batik is a part of the values of the conceptions that live in the realm of mind of most people in things they consider exceptionally noble. Even some batik motifs produced by our ancestors still occupy a spirit that is not defeated by other human cultural products until today. Batik still has cultural noble values which are always considered to be able to provide respectable values by the society and particuar classes in society. Meanwhile, economic value roughly means one of the kinds of values that underlie the actions of a person or group of people based on consideration of the presence or absence of financial benefits as a result of that action.

Therefore, it is surely clear that cultural values are the result of a human conception that produces a cultural product in the form of crafts. Like batik, if done with financial considerations will bring economic benefits, especially for people involved in the ongoing cultural process. Meanwhile, protection from hereditary cultural processes runs in certain regions or geographies, which have reputation, quality and characteristics will get protection from Geographical Indications. The number of handicrafts obtained by the Geographical Indications registration is still small, even though Indonesia is exteremely rich in handicraft products with high aesthetic value.

\section{Conclusion}

Based on the field data, it was found that there are centers of traditional batik crafts in Cirebon District that have the potential to be registered with Geographical Indications (GI). The potential strength is indicated by obtaining the reputation, quality, characteristics and environmental/geographical factors possessed as potential from the registration of Geographical Indications.

Data of history, number of crafters, ornamental variety of Cirebon batik, batik crafters groups that have been accommodated by the association are supporting data that can be identified and compiled to be actualized into a complete Geographical Indication registration document. Accordingly, the data of the condition in the field located in the batik craft center 
area in Cirebon can be used as an attachment to support the registration of the GI of Cirebon batik. With all kinds of potentials mentioned above, Cirebon traditional batik handicrafts are very feasible to get recognition and be registered as GI of batik handicraft products as it has all the data needed for GI registration requirements at Ministry of Law and Human Rights.

\section{Suggestions}

Complete and comprehensive data on the strength map of Cirebon District batik handicrafts found in the Plered Sub-District area including the Trusmi Wetan, Trusmi Kulon, Kaliwulu, Wotgali, Gamel, Sarabau, and Panembahan villages is needed. The data strength of the batik craftsmen includes the number of active batik craftsmen along with the strength of capital, the number of batik craftsmen, the amount of production they produce, the number of batik stamp craftsmen, the craftsmen of handmade canting, the number of batik designers, batik material providers. It is necessary to identify the batik technique, the number of typical ornamental variety of traditional batik, the number of typical ornamental variety outside of traditional batik from outside of Java, which is done by Cirebon batik craftsmen. It is necessary to identify everything related to the problems faced by Cirebon batik craftsmen.

\section{References}

Chaplin, J.P. 2008. Kamus Lengkap Psikologi. Translated by Kartini Kartono. Jakarta: PT Raja Grafindo Persada.

Calvin S. Hall (1959). Sigmund Freud. Suatu pengantar ke dalam ilmu jiwa Sigmund freud. Jakarta. PT. Pembangunan

Djoemena, Nian S., 1986. Ungkapan Sehelai Batik Jakarta: Djambatan.

Hamzuri. 1985. Batik Klasik (Classical Batik). Jakarta: Djambatan.

Honggopuro, Kalinggo. 2002. Batik Sebagai Busana Dalam Tatanan dan Tuntunan. Yayasan Peduli Keraton.

Indonesia Indah Batik 8. Jakarta: Yayasan HarapanKita/BP3 Taman Mini Indonesia Indah.

Irianto, Bambang drh. Makna Simbolik Batik Keraton Cirebon: Deepublish, 2015.

Kudiya, Komarudin . 2018. Kreatifitas Batik Cap dan Tulis. ITB Press Penerbit. Bandung

KBBI, 2016. Kamus Besar Bahasa Indonesia (KBBI).

Lombard, Denys. 2008. Nusa Jawa: Silang Budaya Kajian Sejarah Terpadu Bagian II: Jaringan Asia. Jakarta: PT.

Poerwadarminta. 2007. Kamus Umum Bahasa Indonesia. Jakarta: PN Balai Pustaka.

Ramli, Ahmad dan Risang Ayu, Miranda. (2018). Kekayaan Intelektual Pengantar Indikasi Geografis. PeneribitPT. Alumni - Bandung.

Rosidi, Ajip, dkk. Ensiklopedi Sunda, Jakarta: PT Pustaka Jaya

Rosidi, Ajip ; Ekadjati, Edi S.; Alwasilah, A. Chaedar, 2006, Konferensi Internasional Budaya Sunda (KIBS), Jilid 1, Bandung: Yayasan Kebudayaan Rancage dan PT Dunia Pustaka Jaya

Sugiyono. 2010. Metode Penelitian Pendidikan

Tirta, Iwan. Batik Sebagai lakon, Jakarta: Gaya Favorit Press, 2009 